\title{
Surgical treatment of elderly patients with severe aortic stenosis in the modern era - review
}

\author{
Anna Kwiecień ${ }^{1}$, Tomasz Hrapkowicz ${ }^{1}$, Krzysztof Filipiak ${ }^{1}$, Roman Przybylski², Marcin Kaczmarczyk ${ }^{1}$, \\ Anetta Kowalczuk ${ }^{1}$, Marian Zembala ${ }^{1}$ \\ ${ }^{1}$ Department of Cardiac, Vascular and Endovascular Surgery and Transplantology, Medical University of Silesia in Katowice, \\ Silesian Centre for Heart Diseases, Zabrze, Poland \\ ${ }^{2}$ Department of Cardiovascular Surgery Transplantology Department, John Paul II Hospital, Jagiellonian University Medical \\ College, Krakow, Poland
}

Kardiochirurgia i Torakochirurgia Polska 2018; 15 (3): 188-195

\begin{abstract}
Surgical treatment of severe aortic stenosis offers good early and long-term results, even in elderly patients. Despite the implementation of percutaneous methods for the very high-risk group, surgical valve replacement remains the gold standard. The advanced age of patients should not be the only indicator limiting the possibility of surgery. In this review we present the most important information on the results of aortic stenosis surgical treatment in the groups of older patients. New methods such as percutaneous and minimally invasive methods of surgery are also discussed. Additionally, the presented information is referred to current guidelines for the treatment of severe aortic stenosis.
\end{abstract}

Key words: elderly patients, aortic valve replacement.

\section{Introduction}

Aortic stenosis is the most common primary valvular heart disease. The most common rheumatic pathology in the past, currently due to the appropriate treatment of rheumatic fever it is a rare cause of aortic stenosis. Genetic predisposition, especially the presence of a bicuspid valve, can cause aortic damage even in younger people. Nowadays, however, the development of aortic valve stenosis is strongly related to older age and is associated with the degeneration of this valve, which begins at around 60 years of age and most often causes symptoms in the $7^{\text {th }}$ or $8^{\text {th }}$ decade of life. According to US data (after analysis of 7 studies with a total population of 9723 patients), over $12 \%$ of people over 75 years of age present aortic stenosis and $3.4 \%$ in severe grade [1]. Data from the Central Statistical Office show that men in Poland lived on average 73.9 years, while women

\section{Streszczenie}

Chirurgiczne leczenie ciężkiej stenozy aortalnej przynosi dobre wyniki zarówno krótko-, jak i długoterminowe, nawet u pacjentów w podeszłym wieku. Pomimo wprowadzenia metod przezskórnych przeznaczonych dla pacjentów z grupy wysokiego ryzyka, chirurgiczna wymiana zastawki aortalnej jest złotym standardem. Zaawansowany wiek pacjentów nie powinien być jedynym czynnikiem ograniczającym możliwość wykonania operacji. W artykule zaprezentowano najważniejsze informacje na temat wyników chirurgicznej (klasycznej) wymiany zastawki aortalnej u starszych pacjentów. Omówiono również leczenie przezcewnikowe oraz małoinwazyjną metodę chirurgicznej wymiany zastawki aortalnej. Przedstawione dane odnoszą się do obowiązujących wytycznych dotyczących leczenia ciężkiej stenozy aortalnej.

Słowa kluczowe: pacjenci w podeszłym wieku, wymiana zastawki aortalnej.

lived 81.9 years (7.7 and 6.7 years respectively longer than in 1990). This longer length of life increases the number of patients with degenerative aortic stenosis.

\section{Pathophysiology, diagnosis, medical management}

Aortic stenosis, currently occurring mainly in the elderly population, was initially considered as a degenerative process with passive deposits of calcium, resulting primarily from the process of aging of this valve ("wear and tear"). Recent studies indicate the involvement of a chronic inflammatory process, similar to those occurring in atherosclerosis, tissue remodeling with lipoprotein deposition, oxidized lipoproteins and calcium, infiltration of inflammatory cells, and osteoblast activation. It is emphasized that the degeneration of the valve is active, not passive as mentioned earlier. 
This process is based on the interaction between genetically conditioned, biochemical and humoral factors. Risk factors associated with acceleration of the disease and its worse prognosis include age, diabetes, hypertension, smoking, male gender, metabolic syndromes, dyslipidemia, diabetes, hypercholesterolemia, low high-density lipoprotein (HDL) levels, elevated level of apolipoprotein B, endothelial dysfunction, elevated level of cytokines and C-reactive protein (CRP), and decreased adiponectin level. The pathogenesis of aortic stenosis seems to be similar to the pathogenesis of atherosclerosis. Risk factors are defined as cardiometabolic or valvulo-metabolic. A gradual process initiated by remodeling of the tissue leads to significant calcification of the valve, resulting in narrowing of the left ventricle outflow, which leads to overload of the left ventricle and consequently to its systolic and diastolic dysfunction [2-5].

According to a study by Pellikka et al., the majority of patients with asymptomatic but haemodynamically significant aortic stenosis will develop characteristic symptoms within 5 years. Sudden cardiac death will occur in 1\%. Age, chronic renal failure, and limited physical activity are independent predictors of death. The period without adverse cardiac events (including death) in 1 year was $80 \%$, after 2 years $63 \%$ and $25 \%$ after 5 years [6]. Chizner et al. show that the onset of symptoms is associated with 1-year mortality of $26 \%$, 2 -year mortality of $48 \%$ and 3-year mortality of $57 \%$ [7].

In the assessment of the severity of aortic stenosis the crucial method is echocardiography. Echocardiographic assessment allows confirmation not only of the value of the gradient by the aortic valve, but also of the severity of the disease in the presence of a low-pressure gradient. The aortic valve opening area should be evaluated depending on the size of the flow, pressure gradient and parameters of the left ventricle, such as wall thickness, left ventricular function, calcification, arterial blood pressure, and functional status [3]. The conservative treatment of severe aortic stenosis is ineffective. Also, the treatment of heart failure in the course of this disease has a different character than in the case of circulatory insufficiency of other causes. Therefore, no form of conservative treatment improves the prognosis of patients. The only effective method is intervention on the aortic valve. Three methods of intervention available at the moment are valvuloplasty, surgical valve replacement (SAVR) and transcatheter aortic valve implantation (TAVI). The effectiveness of valvuloplasty is limited, and it is reserved for urgent cases as a bridge for further intervention, as a palliative or as a diagnostic method.

According to the ESC guidelines [3], aortic valve intervention is indicated in symptomatic patients with severe, high-gradient aortic stenosis (IB) and symptomatic patients with severe low-flow, low-gradient stenosis in the presence of low LV ejection fraction and evidence of flow (contractile) reserve excluding pseudosevere aortic stenosis (IC). Intervention should also be considered (Ila) in symptomatic patients with severe low-flow, low-gradient stenosis and normal EF or in patients with reduced EF without flow (contractile) reserve, particularly when $\mathrm{CT}$ calcium scoring con- firms severe aortic stenosis. In the case of the presence of severe comorbidities when the intervention is unlikely to improve quality of life or survival, the intervention should not be performed (IIIC). The choice of treatment method (SAVR or TAVI) in elderly patients should be based on the assessment of risk factors. The surgical method is preferred in patients with low surgical risk (STS risk or EuroSCORE II $<4 \%$ or logistic EuroSCORE $\mid<10 \%)$. The surgical method should also be carefully considered in the presence of other risk factors, not included in the above scales, such as frailty (occurring in more than $30 \%$ of patients over 80 years of age), porcelain aorta or sequelae of chest radiation. In the presence of these factors or higher than the above-mentioned operative risks resulting from the STS or EuroSCORE calculations, individual patient analysis within the framework of the Heart Team should be performed and the treatment should be determined by SAVR or TAVI depending on other factors (e.g. the possibility of vascular access). For patients who are not candidates for SAVR, a TAVI procedure is recommended, particularly in the case of older patients if endovascular access is available (IB).

Surgical replacement of the aortic valve in asymptomatic patients, eligible for this operation, should be performed in the presence of severe aortic stenosis and left ventricular dysfunction (LVEF $<50 \%$ ) or if the result of the exercise test documents symptoms associated with stenosis or there is a decrease in the arterial pressure below the baseline (IB). Similarly, in patients with asymptomatic severe aortic stenosis and normal EF without abnormalities in the exercise test, surgery should be considered if one of the parameters is present: very severe stenosis ( $\max >5.5 \mathrm{~m} / \mathrm{s}$ ), severe calcification and the rate of $V \max \geq 0.3 \mathrm{~m} / \mathrm{s} /$ year, a significant increase in brain natriuretic peptide (BNP) concentration or severe pulmonary hypertension.

The patient's age and probability of survival more than 1 year after treatment are important factors of Heart Team selection between SAVR and TAVI [8]. Other factors supporting the consideration of TAVI are previous cardiac surgery and reduced mobility or other factors affecting the rehabilitation after cardiac surgery [3].

Important information is that age itself should not be the decisive factor in the choice of treatment strategy (in particular a factor affecting the decision of denial surgical treatment). According to the Euro Heart Survey Study as many as $33 \%$ of older patients with symptomatic, severe aortic stenosis are disqualified from surgery. The decisive factors are, apart from a low left ventricle ejection fraction, the patient's advanced age [9]. The decision to deny surgery in older patients results in a significant decrease in survival in the group treated conservatively, even after comparing groups evaluated by propensity matching analysis [10].

\section{Aortic valve replacement surgery results}

In the study of the Society of Thoracic Surgeons (Society of Thoracic Surgeons Adult Cardiac Surgery Database - STS ACSD) evaluating 145911 patients over 64 years of age operated on for aortic stenosis, perioperative mortality 
was $3.9 \%$ in patients undergoing isolated AVR (in patients with STS risk $<5 \%$, mortality was $2.5 \%$, in those with STS risk between 5 and $9 \%$ it was $10 \%$, and in patients with STS risk > 10\% (mean age 81 ) it was up to $17.2 \%$. However, it should be noted that this analysis included patients who were also operated on in the early 90s (follow-up period 1991-2007) [11]. Dimarakis et al. evaluated SAVR results in high-risk patients who could not undergo the TAVI procedure. The study group included 28 elderly patients (mean age: $78.4 \pm 9.2$ ), characterized by high predicted operational risk (mean EuroSCORE: $10.0 \pm 3.6$, mean logistic EuroSCORE: $19.9 \pm 18.8$ ). The perioperative mortality rate in such a high risk group of patients was only $4 \%$ and the survival rate in almost 1-year observation was $81 \%$. The authors emphasize that the improvement of mortality and fewer neurological complications after surgical aortic valve replacement had the effect of introducing axillary artery cannulation in patients at risk in order to minimize manipulation of the aorta. Unfortunately, a significant percentage of postoperative complications were observed (renal failure $21 \%$, atrial fibrillation $25 \%$, stimulator implantation $7 \%$, infections $7 \%$, reoperation due to bleeding $7 \%$, tracheostomy $14 \%$ ). After the operation the patients reported the quality of life as satisfactory. The deterioration in the quality of life was affected by comorbid diseases, but not due to heart disease [12]. Vasques et al. in a meta-analysis reviewed 48 papers with the results of isolated SAVR in patients over 80 years of age. Perioperative mortality was assessed at $6.7 \%$. The authors noted a decrease in perioperative mortality in the last few years, associated with a significant improvement in perioperative care - the mortality of $5.8 \%$ was observed in 18 papers published in 2000-2006 whereas it was $7.5 \%$ in 30 papers from 1982-1999 [13]. In a study by Smith et al. the outcomes of SAVR and TAVI in high-risk elderly patients with significant aortic stenosis are presented. Perioperative mortality after SAVR was $6.5 \%$, stroke occurred in $2.1 \%$, vascular complications in $3.2 \%$, bleeding in $19.5 \%$, and atrial fibrillation in $16.0 \%$ [14]. Langanay et al. observed that the early mortality of the entire cohort of elderly patients after SAVR decreased with time due to medical progress from $6.2 \%$ in 1990 to $4.2 \%$ in 2010 [15]. Very good postoperative results were published by Dell'Amore et al. Perioperative mortality was only $4.3 \%$ in patients with mean age of 82 years. Urgent surgery, left ventricle ejection fraction lower than 35\%, prolonged aortic clamp-time, the need of intra-aortic balloon pump, prolonged ventilation, renal failure, postoperative infarction, and reoperation due to bleeding were independent predictors of perioperative mortality. One-, three- and five-year survival was $97.1 \%$, $92.2 \%$ and $82.4 \%$, respectively [16]. Similarly satisfactory results of long-term survival in patients over 80 years after SAVR were presented by Costa et al. In this analysis the 1 -, 3 - and 5-year survival rates were $85 \%, 81 \%$, and $59 \%$, respectively, and the majority of patients (96\%) remained in NYHA functional class I or II at follow-up [17]. In the Leontyev et al. study, the survival of low, intermediate and high risk patients depending on the risk group calculated by logistic EuroSCORE after 1 year was $90 \%, 78 \%$, and $69 \%$, after 5 years $70 \%, 53 \%, 38 \%$, and after 8 years 38\%, 33\%, $21 \%$. Factors worsening the survival rate were heart failure, urgency of the procedure, prior stroke or TIA and higher risk [18]. In the afore-mentioned meta-analysis, Vasques et al. observed a very good survival rate after $1,3,5$ and 10 years $87.6 \%, 78.7 \%, 65.4 \%$ and $29.7 \%$ [13]. Pierard et al. in the examined group of patients (mean age: 83 ) with significant aortic stenosis and combined aortic valve disease assessed that the perioperative mortality rate was $5 \%$ and mortality predictors were the severity of the disease in terms of pre-operative symptoms. The presence of preoperative chronic obstructive pulmonary disease worsened long-term survival [10]. Interesting observations were presented by Krane et al. The authors analyzed the results of elderly patients undergoing SAVR and SAVR with CABG. Among 303 patients over 79 years of age who underwent isolated aortic valve replacement, the average survival was 6.1 years. In the group of patients who underwent SAVR or SAVR with CABG, the overall survival after 1 year, 5 years and 10 years was $81.6 \pm 1.2 \%, 60.4 \pm 1.9 \%$, and $23.3 \pm 2.6 \%$ and, what is extremely important, showed no significant differences compared to survival of the general population. Creatinine levels higher than $1.3 \mathrm{mg} / \mathrm{dl}$, atrial fibrillation in the preoperative period, and post-operative prolonged ventilation were independent predictors of worse long-term survival [19]. Di Eusanio et al. reported excellent outcomes in octogenarians (mean logistic Euro-SCORE: 13.0\%) after SAVR. Hospital mortality was $4.5 \%$ and stroke rate $1.3 \%$ and at 6 years the survival rate was similar to the expected survival of the age- and sex-matched population [20]. The assessment of patients' quality of life after SAVR was mostly affected by comorbidities, but was not related to heart disease. Comorbidities are common in older people and may impede the assessment whether the patient will benefit from valve replacement surgery. They affect not only the quality of life, but also the length of life, regardless of valvular disease. Nevertheless older patients benefit from aortic valve replacement surgery in the aspect of improving the quality of life [21].

Surgical replacement of the aortic valve recently offers new, minimally invasive approaches, possibly shortening the period of rehabilitation and improving the quality of life in older patients. These methods are associated with limited access (ministernotomy, minithoracotomy) or shortening of the duration of extracorporeal circulation and/or aortic cross-clamp time (sutureless valves) [22]. Gilmanov et al. analyzed two propensity-matched groups of patients aged over 80 years who underwent mini-AVR (thoracotomy) and conventional sternotomy. The minimally invasive group had lower stroke incidence, earlier extubation and shorter hospital stay. The in-hospital mortality and longterm survival at 5 years were similar [23]. Moscarelli et al. in a systematic review of non-randomized studies found miniAVR to have mortality comparable to full sternotomy, significantly reduced postoperative length of stay, and no significant difference in CPB and aortic cross-clamp times [24]. Santarpino et al. observed patients undergoing sutureless valve implantation with no differences reported between 


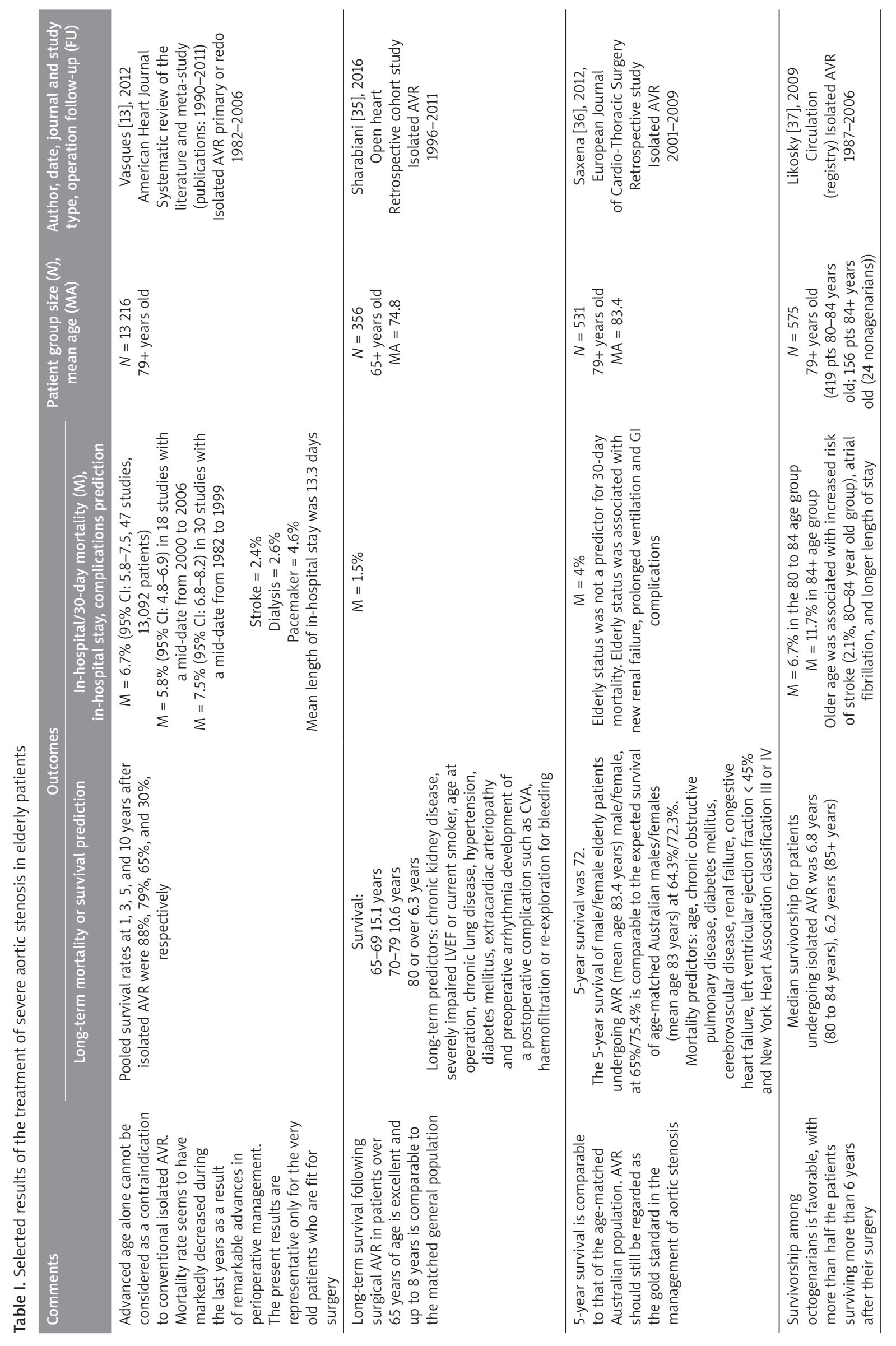




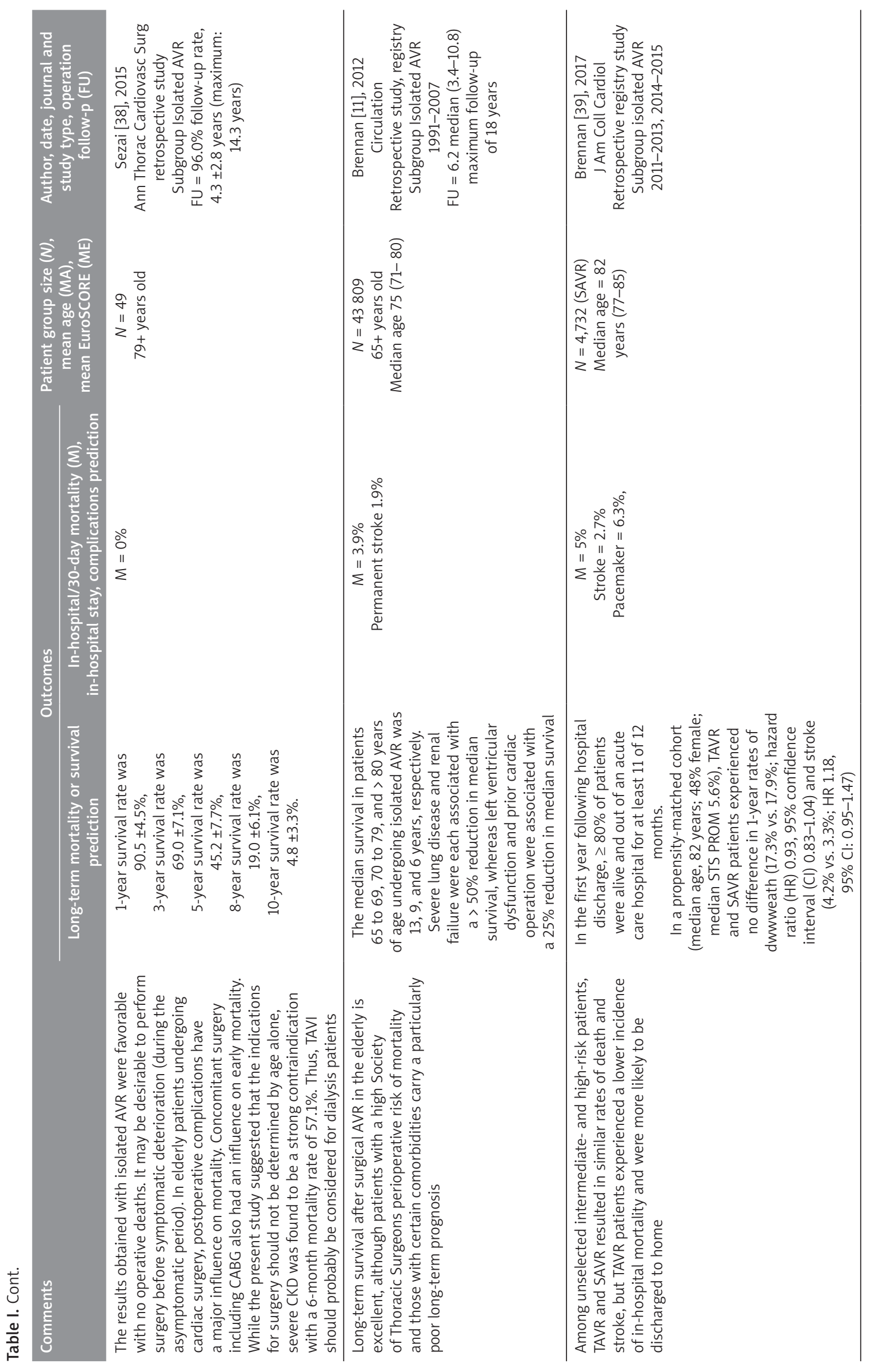



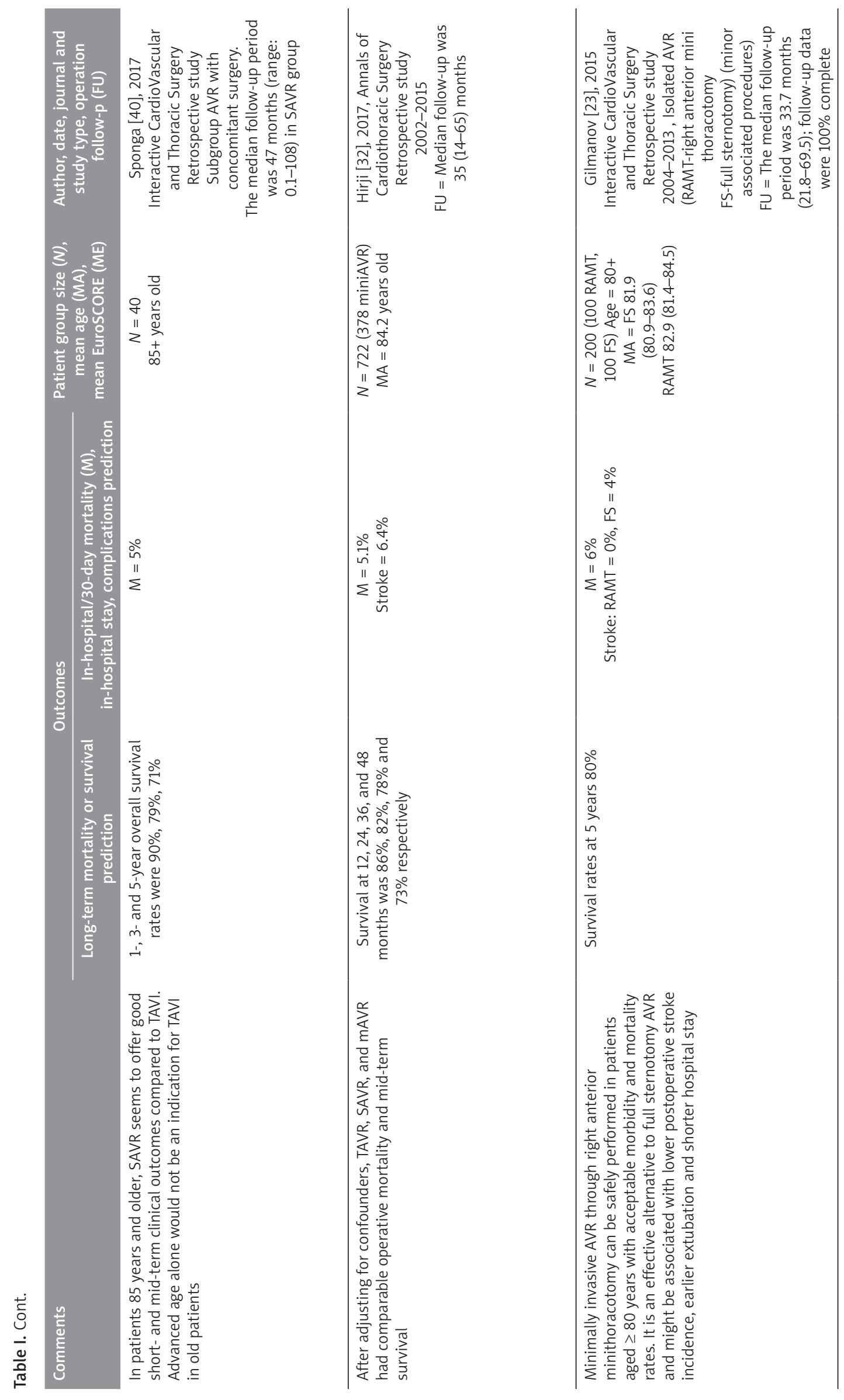
the mini-AVR groups (age $\geq 80$ years and $\leq 80$ years) [25]. In the study by Lamelas et al. a mini-AVR (mini-thoracotomy) group was compared with a full sternotomy group. The composite of mortality and morbidity was significantly lower in the minimally invasive group due to a lower incidence of renal failure, reduced intubation time, less wound infection and fewer deaths [26]. Selected results of the treatment of severe aortic stenosis in elderly patients are presented in Table I.

Recently, TAVI has emerged as an alternative treatment option to SAVR for patients with severe aortic stenosis with improved short-term quality of life in the surgical high-risk patients. The PARTNER B trial (with a medical therapy only control group) and CoreValve U.S. Extreme Risk Pivotal Trial showed similar results in improvements in both diseasespecific and generic health status through 1-year follow-up $[27,28]$. Siontis et al. in their meta-analysis of trials comparing TAVI and SAVR concluded that TAVI is associated with a significant survival benefit throughout 2 years of follow-up and this superiority is observed irrespective of the TAVI device, particularly pronounced among patients undergoing transfemoral TAVI and in females [29]. On the other hand, the data from the STS/ACC Transcatheter Valve Therapies Registry on 12,182 patients (mean age: 84 years) indicated that only $60 \%$ of TAVI patients were discharged home and the 30-day mortality was 7\% [30]. In the SURTAVI trial, the event rate for all-cause mortality at 30 days was 2.2\% for TAVR and $1.7 \%$ for SAVR, with comparable incidence rates at 1 year (6.7\% vs. $6.8 \%)$ and 2 years $(11.4 \%$ vs. $11.6 \%$ ) [31]. The study by Hirji et al. showed that TAVR (regardless of approach), SAVR, and mini-AVR had comparable operative mortality and mid-term survival [32]. The very good results of SAVR were confirmed in the analysis of PARTNER 2a trial by Thourani et al. The authors concluded that SAVR in intermediate-risk patients had a hospital mortality of $4.1 \%$ and excellent results at 2 years [33]. Khan et al. in meta-analysis suggest that TAVI can provide a similar mortality outcome compared with SAVR in low to intermediate surgical risk patients with critical aortic stenosis. However, both procedures are associated with their own array of adverse events. In the analysis stratified by study design, no significant differences were noted in the RCTs for stroke, whereas TAVI was better than SAVR in matched studies in the short term only [34]. The lack of long-term data after TAVI is still the largest weakness of this procedure in non-high-risk patients. However, there is no doubt that transcatheter aortic valve replacement is an alternative treatment for elderly, high-risk or inoperable patients with aortic stenosis. Future technical developments and randomized trials will probably establish indications for elderly, lower-risk patients for SAVR or TAVI.

\section{Disclosure}

The authors report no conflict of interest.

\section{References}

1. Osnabrugge RL, Mylotte D, Head SJ, Van Mieghem NM, Nkomo VT, LeReun CM, Bogers AJ, Piazza N, Kappetein AP. Aortic stenosis in the elderly: disease prevalence and number of candidates for trans-catheter aortic valve replacement: a meta-analysis and modeling study. J Am Coll Cardiol 2013; 62: 1002-1012.

2. Freeman RV, Otto CM. Spectrum of calcific aortic valve disease: pathogenesis, disease progression, and treatment strategies. Circulation 2005; 111: 3316-3326.

3. Baumgartner H, Falk V, Bax JJ, De Bonis M, Hamm C, Holm PJ, lung B, Lancellotti P, Lansac E, Rodriguez Muńoz D, Rosenhek R, Sjögren J, Tornos Mas P, Vahanian A, Walther T, Wendler O, Windecker S, Zamorano JL; ESC Scientific Document Group. 2017 ESC/EACTS Guidelines for the management of valvular heart disease. Eur Heart J 2017; 38: 2739-2791.

4. Mathieu P, Despres JP, Pibarot P. The 'valvulo-metabolic' risk in calcific aortic valve disease. Can J cardiol 2007; 23 Suppl B: 32B-39B.

5. Rajamannan NM, Evans FJ, Aikawa E, Grande-Allen KJ, Demer LL, Heistad DD, Simmons CA, Masters KS, Mathieu P, O'Brien KD, Schoen FJ, Towler DA, Yoganathan AP, Otto CM. Calcific aortic valve disease: not simply a degenerative process: a review and agenda for research from the National Heart and Lung and Blood Institute Aortic Stenosis Working Group. Executive summary: calcific aortic valve disease-2011 update. Circulation 2011; 124: 1783-1791.

6. Pellikka PA, Sarano ME, Nishimura RA, Malouf JF, Bailey KR, Scott CG, Barnes ME, Tajik AJ. Outcome of 622 adults with asymptomatic, hemodynamically significant aortic stenosis during prolonged follow-up. Circulation 2005; 111: 3290-3295.

7. Chizner MA, Pearle DL, deLeon AC Jr. The natural history of aortic stenosis in adults. Am Heart J 1980; 99: 419-424.

8. Vahanian A, Alfieri O, Al-Attar N, Antunes MJ, Bax J, Cormier B, Cribier A, De Jaegere P, Fournial G, Kappetein AP, Kovac J, Ludgate S, Maisano F, Moat N, Mohr FW, Nataf P, Pierard L, Pomar JL, Schofer J, Tornos P, Tuzcu M, van Hout B, von Segesser LK, Walther T. Transcathetervalve implantation for patients with aortic stenosis: a position statement from the European Association of Cardio-Thoracic Surgery (EACTS) and the European Society of Cardiology (ESC), in collaboration with the European Association of Percutaneous Cardiovascular Interventions (EAPCI). Eur Heart J 2008; 29: 1463-1470.

9. Iung B, Cachier A, Baron G, Messika-Zeitoun D, Delahaye F, Tornos P, Gohlke-Bärwolf C, Boersma E, Ravaud P, Vahanian A. Decision-making in elderly patients with severe aortic stenosis: why are so many denied surgery? Eur Heart J 2005; 26: 2714-2720.

10. Pierard S, Seldrum S, de Meester C, Pasquet A, Gerber B, Vancraeynest D, El Khoury G, Noirhomme P, Robert A, Vanoverschelde JL. Incidence, determinants, and prognostic impact of operative refusal or denial in octogenarians with severe aortic stenosis. Ann Thorac Surg 2011; 91: 1107-1112.

11. Brennan JM, Edwards FH, Zhao Y, O'Brien SM, Douglas PS, Peterson ED. Long-term survival after aortic valve replacement among high-risk elderly patients in the United States: insights from the Society of Thoracic Surgeons Adult Cardiac Surgery Database, 1991 to 2007. Circulation 2012; 126: 1621-1629.

12. Dimarakis I, Rehman SM, Grant SW, Saravanan DM, Levy RD, Bridgewater B, Kadir I. Conventional aortic valve replacement for high-risk aortic stenosis patients not suitable for transcatheter aortic valve implantation: feasibility and outcome. Eur J Cardiothorac Surg 2011; 40: 743-748.

13. Vasques F, Messori A, Lucenteforte E, Biancari F. Immediate and late outcome of patients aged 80 years and older undergoing isolated aortic valve replacement: a systematic review and meta-analysis of 48 studies. Am Heart J 2012; 163: 477-485.

14. Smith CR, Leon MB, Mack MJ, Miller DC, Moses JW, Svensson LG, Tuzcu EM, Webb JG, Fontana GP, Makkar RR, Williams M, Dewey T, Kapadia S, Babaliaros V, Thourani VH, Corso P, Pichard AD, Bavaria JE, Herrmann HC, Akin JJ, Anderson WN, Wang D, Pocock SJ; PARTNER Trial Investigators. Transcatheter versus surgical aortic valve replacement in high-risk patients. N Engl J Med 2011; 364: 2187-2198.

15. Langanay T, Rouze S, Tomasi J. Conventional aortic valve replacement in 2005 elderly patients: a 32-year experience. Eur J Cardiothorac Surg 2018; 54: 446-452.

16. Dell'Amore A, Aquino TM, Pagliaro M, Lamarra M, Zussa C. Aortic valve replacement with and without combined coronary bypass grafts in very elderly patients: early and long-term results. Eur J Cardiothorac Surg 2012; 41: 491-498. 
17. Costa S, Rijo D, Monteiro JP, Martins D, Santos Paulo N, Vouga L, Guerra M. Long-term outcomes in octogenarians following isolated aortic valve replacement. Rev Port Cir Cardiotorac Vasc 2017; 24: 133.

18. Leontyev S, Walther T, Borger MA, Lehmann S, Funkat AK, Rastan A, Kemp fert J, Falk V, Mohr FW. Aortic valve replacement in octogenarians: utility of risk stratification with EuroSCORE. Ann Thorac Surg 2009; 87: 1440-1445.

19. Krane M, Voss B, Hiebinger A, Deutsch MA, Wottke M, Hapfelmeier A, Badiu CC, Bauernschmitt R, Lange R. Twenty years of cardiac surgery in patients aged 80 years and older: risks and benefits. Ann Thorac Surg 2011; 91: 506-513.

20. Di Eusanio M, Fortuna D, Cristell D, Pugliese P, Nicolini F, Pacini D, Gab bieri D, Lamarra M; RERIC (Emilia Romagna Cardiac Surgery Registry) Investigators. Contemporary outcomes of conventional aortic valve replacement in 638 octogenarians: insights from an Italian Regional Cardiac Surgery Registry (RERIC). Eur J Cardiothorac Surg 2012; 41: 1247-1252.

21. Rumsfeld JS. Valve surgery in the elderly: question of quality (of life)? J Am Coll Cardiol 2003; 42: 1215-1217.

22. Kaczmarczyk M, Szałański P, Zembala M, Filipiak K, Karolak W, Wojarski J, Garbacz M, Kaczmarczyk A, Kwiecień A, Zembala M. Minimally invasive aortic valve replacement - pros and cons of keyhole aortic surgery. Kardiochir Torakochir Pol 2015; 12: 103-110.

23. Gilmanov D, Farneti PA, Ferrarini M, Santarelli F, Murzi M, Miceli A, Solinas $M$, Glauber M. Full sternotomy versus right anterior minithoracotomy for isolated aortic valve replacement in octogenarians: a propensitymatched study dagger. Interact Cardiovasc Thorac Surg 2015; 20: 732-741.

24. Moscarelli M, Emmanuel S, Athanasiou T, Speziale G, Fattouch K, Casula R. The role of minimal access valve surgery in the elderly. A meta-analysis of observational studies. Int J Surg 2016; 33 Pt A: 164-171.

25. Santarpino G, Pfeiffer S, Vogt F, Hinzmann M, Concistrè G, Fischlein T. Advanced age per se should not be an exclusion criterion for minimally invasive aortic valve replacement. J Heart Valve Dis 2013; 22: 455-459.

26. Lamelas J, Sarria A, Santana O, Pineda AM, Lamas GA. Outcomes of minimally invasive valve surgery versus median sternotomy in patients age 75 years or greater. Ann Thorac Surg 2011; 91: 79-84.

27. Reynolds MR, Magnuson EA, Lei $Y$, Leon MB, Smith CR, Svensson LG, Webb JG, Babaliaros VC, Bowers BS, Fearon WF, Herrmann HC, Kapadia S, Kodali SK, Makkar RR, Pichard AD, Cohen DJ. Placement of Aortic Transcatheter Valves I. Health-related quality of life after transcatheter aortic valve replacement in inoperable patients with severe aortic stenosis. Circulation 2011; 124: 1964-1972.

28. Osnabrugge RL, Arnold SV, Reynolds MR, Magnuson EA, Wang K, Gau diani VA, Stoler RC, Burdon TA, Kleiman N, Reardon MJ, Adams DH, Popma JJ, Cohen DJ, CoreValve USTI. Health status after transcatheter aortic valve replacement in patients at extreme surgical risk: results from the CoreValve U.S. trial. JACC Cardiovasc Interv 2015; 8: 315-323.

29. Siontis GCM, Praz F, Pilgrim T, Mavridis D, Verma S, Salanti G, Søndergaard L, Jüni $P$, Windecker $S$. Transcatheter aortic valve implantation vs. surgical aortic valve replacement for treatment of severe aortic stenosis: a meta-analysis of randomized trials. Eur Heart J 2016; 37: 3503-3512.

30. Holmes DR Jr, Brennan JM, Rumsfeld JS, Dai D, O’Brien SM, Vemulapalli S, Edwards FH, Carroll J, Shahian D, Grover F, Tuzcu EM, Peterson ED,
Brindis RG, Mack MJ; STS/ACC TVT Registry. Clinical outcomes at 1 year following transcatheter aortic valve replacement. JAMA 2015; 313: 1019-1028.

31. Reardon MJ, Van Mieghem NM, Popma JJ, Kleiman NS, Søndergaard L, Mumtaz M, Adams DH, Deeb GM, Maini B, Gada H, Chetcuti S, Gleason T, Heiser J, Lange R, Merhi W, Oh JK, Olsen PS, Piazza N, Williams M, Windecker S, Yakubov SJ, Grube E, Makkar R, Lee JS, Conte J, Vang E, Nguyen H, Chang Y, Mugglin AS, Serruys PW, Kappetein AP; SURTAVI Investigators. Surgical or transcatheter aortic-valve replacement in intermediate-risk patients. N Engl J Med 2017; 376: 1321-1331.

32. Hirji SA, Ramirez-Del Val F, Kolkailah AA, Ejiofor II, McGurk S, Chowdhury R, Lee J, Shah PB, Sobieszczyk PS, Aranki SF, Pelletier MP, Shekar PS, Kaneko T. Outcomes of surgical and transcatheter aortic valve replacement in the octogenarians - surgery still the gold standard? Ann Cardiothorac Surg 2017; 6: 453-462.

33. Thourani VH, Forcillo J, Szeto WY, Kodali SK, Blackstone EH, Lowry AM, Semple M, Rajeswaran J, Makkar RR, Williams MR, Bavaria JE, Herrmann HC, Maniar HS, Babaliaros VC, Smith CR, Trento A, Corso PJ, Pichard AD, Miller DC, Svensson LG, Kapadia S, Ailawadi G, Suri RM, Greason KL, Hahn RT, Jaber WA, Alu MC, Leon MB, Mack MJ; PARTNER Trial Investigators. Outcomes in 937 intermediate-risk patients undergoing surgical aortic valve replacement in PARTNER-2A. Ann Thorac Surg 2018; 105: 1322-1329.

34. Khan S, Lone A, Saleem M, Kaluski E. Transcatheter vs surgical aortic-valve replacement in low to intermediate-surgical-risk candidates: a meta-analysis and systematic review. Clin Cardiol 2017; 40: 974-981.

35. Sharabiani MT, Fiorentino F, Angelini GD, Patel NN. Long-term survival after surgical aortic valve replacement among patients over 65 years of age. Open Heart 2016; 3: e000338.

36. Saxena A, Poh CL, Dinh DT, Reid CM, Smith JA, Shardey GC, Newcomb AE. Early and late outcomes after isolated aortic valve replacement in octogenarians: an Australasian Society of Cardiac and Thoracic Surgeons Cardiac Surgery Database Study. Eur J Cardiothorac Surg 2012; 41: 63-68.

37. Likosky DS, Sorensen MJ, Dacey LJ, Baribeau YR, Leavitt BJ, DiScipio AW, Hernandez F Jr, Cochran RP, Quinn R, Helm RE, Charlesworth DC, Clough RA, Malenka DJ, Sisto DA, Sardella G, Olmstead EM, Ross CS, O'Connor GT; Northern New England Cardiovascular Disease Study Group. Long-term survival of the very elderly undergoing aortic valve surgery. Circulation 2009; 120 (11 Suppl): S127-S133.

38. Sezai A, Osaka S, Yaoita H, Ishii Y, Arimoto M, Hata H, Shiono M. Early and long-term outcomes in Japanese patients aged 80 years or older undergoing conventional aortic valve replacement. Ann Thorac Cardiovasc Surg 2015; 21: 247-253.

39. Brennan JM, Thomas L, Cohen DJ, Shahian D, Wang A, Mack MJ, Holmes DR, Edwards FH, Frankel NZ, Baron SJ, Carroll J, Thourani V, Tuzcu EM, Arnold SV, Cohn R, Maser T, Schawe B, Strong S, Stickfort A, Patrick-Lake E, Graham FL, Dai D, Li F, Matsouaka RA, O’Brien S, Li F, Pencina MJ, Peterson ED. Transcatheter versus surgical aortic valve replacement: propensitymatched comparison. J Am Coll Cardiol 2017; 70: 439-450.

40. Sponga S, Isola M, Bagur R, Torracchi L, Mazzaro E, Grillo MT, Lechiancole A Pompei E, Armellini I, Livi U. Transcatheter aortic valve implantation versus surgical aortic valve replacement in patients over 85 years old. Interact Cardiovasc Thorac Surg 2017; 25: 526-532 